\title{
Old Arithmetic Books: Mathematics in Spain in the First Half of the Sixteenth Century
}

\author{
María José Madrid ${ }^{1}$, Alexander Maz-Machado ${ }^{2 *}$, Carmen López ${ }^{3}$, Carmen León-Mantero ${ }^{2}$ \\ ${ }^{1}$ Universidad Pontificia de Salamanca, SPAIN \\ 2 Universidad de Córdoba, SPAIN \\ ${ }^{3}$ Universidad de Salamanca, SPAIN \\ *CORRESPONDENCE: $\triangle$ ma1mamaa@uco.es
}

\begin{abstract}
During the sixteenth century, a relevant number of books related to practical arithmetic were published in Spain. This paper presents a comparative study that aims to identify the object and target of five old mathematics books and the main contents of these books. In order to do so, all the contents and all the examples found in five arithmetic books written during the first half of the 16th century were identified and categorised. A historical-mathematical analysis using a content analysis technique was then applied. The results show the authors' concerns about mathematics at the time and the different contents that were included in some arithmetic books of this century.
\end{abstract}

Keywords: history of mathematics education, mercantile arithmetic, old mathematics books, sixteenth century

\section{INTRODUCTION}

Mathematics education is a field that has developed over the last two centuries because mathematicians and educators have turned their attention to how and what part of mathematics is, or can be, taught and learned in schools (Kilpatrick, 1994). Among the research on mathematics education is included the research focused on the history of mathematics and mathematics education.

The main purpose of research on the history of mathematics is to know how concepts developed: that is, to present its past and its development until present time. This field of research also looks for motivations, causes, and understandings of the concepts in a more general sense (Grattan-Guinness, 2004); therefore, the history of mathematics allows knowing the motivations and the origin of a mathematical concept or an idea, as well as its development or the different points of view that its evoked (Jahnke, 2001). However, for the historical comprehension of mathematics, other types of knowledge are also necessary (Garciadiego, 2002). In this sense, it is also relevant to know social, economic and scientific aspects of the analysed period. Moreover, careful consideration of the didactic principles included in the transmission of these contents is relevant. And history of mathematics education allows discovering moments, situations, institutions, topics or mathematicians that at some point encourage a change of direction or an advance in the history of mathematics or mathematics education (Maz-Machado \& Rico, 2013).

However, it should be considered that history of mathematics and history of mathematics education have experienced considerably extensive intersections. For example, from the early periods until the Middle Ages,

Article History: Received 2 April $2019 \bullet$ Revised 20 July $2019 \bullet$ Accepted 7 August 2019

(c) 2020 by the authors; licensee Modestum Ltd., UK. Open Access terms of the Creative Commons Attribution 4.0 International License (http://creativecommons.org/licenses/by/4.0/) apply. The license permits unrestricted use, distribution, and reproduction in any medium, on the condition that users give exact credit to the original author(s) and the source, provide a link to the Creative Commons license, and indicate if they made any changes. 
both histories deal with practically the same documents and personalities, although they are studied from different perspectives (Schubring, 2014).

To summarise, research on history of mathematics helps to understand how concepts and mathematical ideas have developed over the years; research on the history of mathematics education elaborates on the knowledge provided by research on history of mathematics and deeps in different didactic aspects related to the teaching-learning process of mathematical concepts and ideas. This research has an educational purpose, because it helps to understand the activity that has been carried out in the classrooms, it provides information on the educational aspects of the analysed period and it could even help both teachers and students in the teaching-learning process.

In this respect, during the last decades diverse discussions about the possibilities of including the history of mathematics and mathematics education in mathematics education have taken place. Authors like Fauvel (1991), Schubring (2006), Jankvist (2009) and many others have presented different reasons to include the history of mathematics in the classroom.

Therefore, there has been an increasing interest in the history of mathematics and mathematics education (Maz-Machado, Madrid, León-Mantero, \& Jiménez-Fanjul, 2017). Proof of this can be found in the amount of monographs focused on the history of mathematics and mathematics education published by some relevant journals. There are even journals that specifically address the history of mathematics, like the BSHM Bulletin: Journal of the British Society for the History of Mathematics or Historia Mathematica. The existence of research groups in this field in different countries such as France, Italy, Spain or Denmark, among others, can be taken as further evidence of such increment. This increase was already relevant at the beginning of the last decade, when the book History in mathematics education: the ICMI study (Fauvel \& van Maanen, 2000) was published and researchers aimed to integrate history in the process of teaching and learning mathematics (Gulikers \& Blom, 2001). Moreover, different studies about the inclusion of history of mathematics in the classroom have been conducted; take, for instance, Hallez (1992) or Clark and Robson (2008). Innovative experiences have also been carried out; for example, the Mac'Tutor History of Mathematics archive (O'Connor \& Robertson, 2019).

Moreover, mathematical knowledge is produced by humans and therefore, it must be influenced by the conceptions and beliefs of those who produce it, and these aspects are reflected in mathematics textbooks (Kjeldsen, 2011).

Textbooks have become an important object of study in research on education and mathematics education. Their relevance in the process of teaching and learning in different subjects, including mathematics, was already reflected by the Cockcroft report (1982), which argues how textbooks are an invaluable aid for teachers during their daily work in the classroom. This has motivated many members of the research community to focus their research on these texts with very different purposes. In fact, Schubring (1987) pointed out textbooks' relevance when he stated that teaching practice is often more determined by the textbooks used for teaching than by ministerial decrees and official syllabuses, hence the relevance of analysing such books. Proof of their relevance in research on mathematics education is for example, that contributions to textbook research have been present in most Symposia of the Spanish Society for Research in Mathematics Education from 1997 to 2015 (Marco-Buzunáriz, Muñoz-Escolano, \& Oller-Marcén, 2016).

Along similar lines, Choppin (2000) stated that, since the 1980s, school textbooks have become a privileged source for both historians of the book and historians of education, which has led to the multiplication of studies about the history of school books.

Researchers on the history of mathematics and mathematics education find in textbooks an outstanding source of information that allows them to approach other periods and gain better understanding of the teaching of this subject through the years. Textbooks, in this case about mathematics, compile the contents that were being explained in each period, so they facilitate comprehension of the evolution of knowledge. Together with the different contents, textbooks also present other didactic aspects that allow understanding how those contents have been taught throughout the years and in different historical periods.

More precisely, old texts allow rebuilding concepts, giving them a context and knowing different approaches to them. They provide a basis on which to argue about the validity of past forms of argument and to find the grounds of the contemporary ones. In the same way, they also provide information about pedagogical aspects: the ways of organizing and presenting contents, their graphic representations, situations, problems and exercises used to explain mathematical concepts and methods in the best possible way (Gómez, 2001). 
For these reasons, some researchers of the history of mathematics and mathematics education focus their research on textbooks. It is reasonable to consider that the subarea of the history of mathematics education that looks at textbooks was inaugurated by Grosse's book about arithmetic textbooks, which was published at the very beginning of the twentieth century, more precisely in 1901 (Schubring, 2014).

Within the last decades, several international researchers in this area have published studies about textbooks, examples of which are Frejd (2012), who made a study about Swedish algebra books written during the nineteenth century, or a comparative analysis of the introduction of calculus in Spanish and French military educational institutions through the eighteenth century books of Pedro Padilla y Arcos and Étienne Bézout (Blanco, 2013).

In Spain, research on the history of mathematics and mathematics education has produced analyses of different old books on the subject; for example, the study of printed books for teaching calculus and geometry (Sierra, Rico, \& Gómez, 1997) or the examples of visualization and use of manipulatives in old mathematics books (Meavilla \& Oller, 2015). The development of different mathematical concepts has also been researched with a basis on textbook analysis, as can be seen in the study about the negative solutions of a geometric problem in textbooks of analytical geometry used in Spain during the 19th century (Sánchez \& González, 2017), or the study about the Metric Decimal System in mathematics texts in Spain (Picado \& Rico, 2012).

\section{Arithmetic Books Published in Spanish during the Sixteenth Century}

This paper focuses on several books about arithmetic that were originally published in Spanish during the first half of the sixteenth century. This particular century stands out in the research on mathematics old books for several reasons.

One of these reasons is the increase in trade relations that took place in Spain during the sixteenth century, due mainly to the exchange of products with America. Moreover, the great diversity of currencies, units of weight and measure in each part of Spain and in the rest of Europe made trade relations complicated. Consequently, a greater number of people needed to develop basic mathematical knowledge, and this contributed to the appearance of many books with this purpose.

Another important reason was the development of the printing press in Spain in the fifteenth century, more specifically in 1472, which helped spread mathematical knowledge in Spanish. This made the publication of different treaties about how to be a good trader or businessman easier at a time when business relations were very relevant, and therefore, it made the acquisition of mathematical knowledge (mostly related to businesses) also easier (Burke, 2000).

The Spanish mathematical activity during the sixteenth century revolved around two different lines. On the one hand, mathematics was treated as a theoretical discipline related to the academic culture, to the universities and their late medieval tradition. On the other hand, it was the base for practical applications in different fields like economy, architecture, or other technical activities (López, 1979).

Practical arithmetic was conceived as a useful tool for solving calculus problems, mostly related to commercial activities. The attention that was paid to teaching it during this century is reflected in the large number of authors who published books on the subject between 1482 and 1600. Salavert (1994) counted a total of 35 authors who published 43 different books that had a total of 77 editions.

Among the main features these 77 books share, one of the most relevant is that most of them are written in the vernacular language. More specifically, up to 67 of them were written in Spanish, which contrasts with previous mathematical books which were generally written in Latin (Salavert, 1994). In this manner, books about mathematics were accessible for more people, since they no longer needed to understand Latin in order to gain access to mathematical knowledge.

Sierra et al. (1997) explained that even though these arithmetic books could not be considered textbooks (at least considering the actual definition of textbooks), they are precursors of them and, what is more important, it is reasonable to think that they were used by teachers. Caunedo (2009) added that these manuals of arithmetic were published to be used as school texts, whose examples and problems were associated with specific situations in which merchants might be involved. Other authors argued that these manuals were used in courses related to arithmetic at university (Carabias, 2012), or even at the House of Trade, a Spanish institution created to control all Spanish trade relations at the time (Salavert, 1990). Therefore, many of these books served as texts for teaching practical arithmetic at different school levels of the time. 
The relevance of the studies focused on the first printed books about mathematics published during the sixteenth century in Europe is also paid attention to in literature on the topic. For example, Swetz (1992) analysed arithmetic texts published in the fifteenth and sixteenth centuries; Carpenter (2013) studied the life and books of the well-known German teacher of arithmetic and writer of mathematical books Adam Riese, who lived between 1492 and 1559; Kiliari, Gagatsis and Papadaki (2015) analysed the first Greek arithmetic book ever printed, written by Manolis Glyzounis and published in 1559.

In addition, different studies about mathematics books published during the sixteenth century in Spain have been carried out. For example, Meavilla and Oller (2014) analysed the contents related to the extraction of roots in the book Tratado de Mathematicas (Treaty of Mathematics) published in 1573 by Juan Perez de Moya or Puig and Fernández (2011) who made a preliminary analysis of Marco Aurel's book. There are also some comparative studies among different books, such as Madrid, Maz-Machado, León-Mantero and LópezEsteban (2017) who analysed the applications of mathematics to everyday life included in several arithmetic books published during this century or Meavilla and Oller (2014) who analysed the algebraic symbolism in three Spanish algebra books of the 16th century.

Following the line of previous research about this topic, this paper aims to unveil several Spanish arithmetic books written during the sixteenth century via a comparative analysis of the object, the target and the contents of five arithmetic books published during the first half of this century.

\section{METHODOLOGY}

Firstly, in order to make a selection from the arithmetic books written during the first half of the 16th century, a set of criteria were considered. These criteria were established following the studies of Maz (2005), Picado (2012) or Madrid (2016):

- Language: only books originally written in Spanish were considered.

- $\quad$ Publication date: each book was first published during the first half of the sixteenth century. However, in some occasions, it was not possible to analyse this first edition due to availability issues and a later one was analysed. Whenever a later edition was analysed, the first edition of the book had nonetheless been published in the set period and not at an earlier or later date.

- $\quad$ Title with the denomination of arithmetic: the existence of several books whose contents were focused exclusively on aspects related to conversions of currencies led to the choice of books whose title explicitly identified teaching of arithmetic.

- Availability of the text: since the books were published long time ago, in some cases access to them is difficult or even impossible today. Therefore, only available books were chosen, this made that the chosen sample was intentional and for convenience.

The arithmetic books selected for this study are hereby listed. The information given is, correspondingly, author, title in Spanish followed by the title in English (translated by the authors of this study) and year of publication:

- Juan De Ortega: Conpusicion de la arte de la arismetica y Juntamente de geometria (Composition of the art of arithmetic and together with geometry) published in 1512.

- Juan Andres: Sumario breve de la practica de la arithmetica (Brief summary of practical arithmetic) published in 1515 .

- Juan Gutierrez: Arte Breve y muy provechoso de quenta castellana y Arithmetica (Brief and very useful art of Castilian count and arithmetic). Some authors considered that its first edition was printed in Toledo in 1531 (Salavert, 1990), but recent studies state that its first edition was printed in 1539 (Ausejo, 2015). The edition analysed was published in 1564 .

- Gaspar De Texeda: Suma de Arihtmetica Practica y de todas Mercaderias con la horden de contadores (Sum of practical arithmetic and all merchandise with the order of accountants) published in 1546.

- Juan de Yciar: Arithmetica Practica (Practical arithmetic) published in 1549.

For the purpose of this study, an exploratory, descriptive and ex post facto research has been carried out. It is a historical research based on the analysis of old books about mathematics. The centres of attention are the main aims of the books, the target audiences for whom the books were written, and the arithmetical contents included in these books.

In order to analyse the books, the categories included in Table 1 were established, following previous studies like those from Maz (2005), Picado (2012) or Madrid (2016). 
Table 1. Aspects considered in analysing each book

\begin{tabular}{|c|c|}
\hline ANALYSE & PECTS \\
\hline Aim of th & \\
\hline Target of & ook \\
\hline & Explicit notion of number or quantity. Numeral decimal system. \\
\hline & Basic operations \\
\hline & Definition of fraction and its operations \\
\hline Contonta & Notion of proportion or exercises related to it, like rule of three, etc. \\
\hline Contents & Extraction of square or cube roots \\
\hline & Progressions \\
\hline & Ideas about geometry \\
\hline & Currencies and measures \\
\hline
\end{tabular}

Table 2. Categorization example

Paragraph
Primeramente es necessario saber/ que progression no es otra cosa sino un
augmento del numero/ el qual procede por todos los numeros respective: porq en
tal proporcion ha destar (o por mejor dezir) se ha de augmentar el segundo mas
que el primero/ como el tercero mas que el segundo/ y el quarto mas q el tercero.
(De Yciar, 1549, p. 11)
[First it is necessary to know/ that progression is not something other than
an increase in the number/ which proceeds for all the respective numbers:
because in such a proportion must be the second (or better said) must increase
the second more than the first/ as the third more than the second / and the fourth
more than the third.]

Assigned category

Contents - Progressions

If at least one example associated to the categories of Table 1 appeared in the book, this book was included in that category.

Content analysis was used as the analysis technique, following the guidelines set by Maz (2009) and used in other studies, similar to the present one, also dealing with the history of mathematics education (Maz \& Rico, 2009; Madrid et al., 2017).

Each one of the paragraphs of each book was characterised as a unit of analysis; these units were read, analysed and then categorised by a triangulation of experts in History of Mathematics Education. Table 2 shows an example of the categorization of the books: the information given is a paragraph of one book in the original Spanish followed by the translation in English (translated by the authors of this study).

\section{RESULTS}

\section{Authors and Their Books: General Aspects Juan de Ortega's book}

The first analysed book was written by Juan de Ortega. He was a member of a religious order, and he taught arithmetic and geometry in Spain and Italy for many years (Rey, 1934). His main contribution to these fields of knowledge was to write one of the first printed books in Spanish about mercantile arithmetic, Conpusicion de la arte de la arismetica y juntamente de geometria: fecha y ordenada por fray Juan de Ortega de la orden de santo domingo de los predicadores (Figure 1 shows the cover of the book). It was first published in Lyon in 1512 and it had numerous other editions published in Spain and in other countries across the following years. 


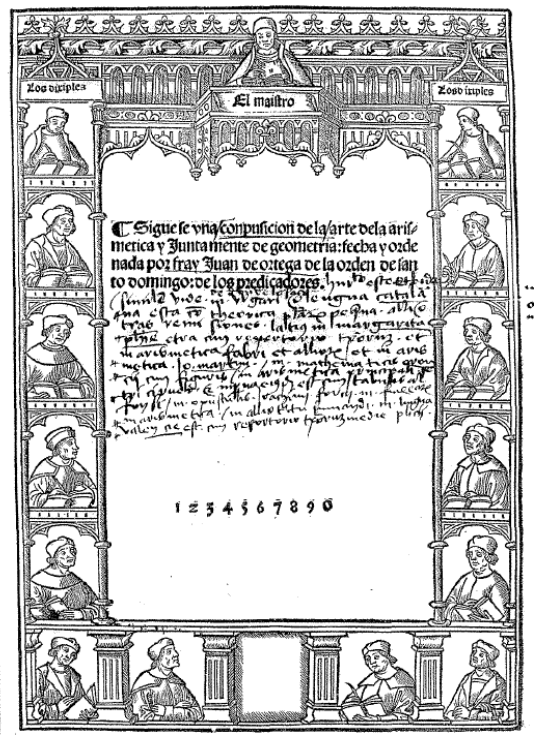

Figure 1. Cover of Juan de Ortega's book (1512)
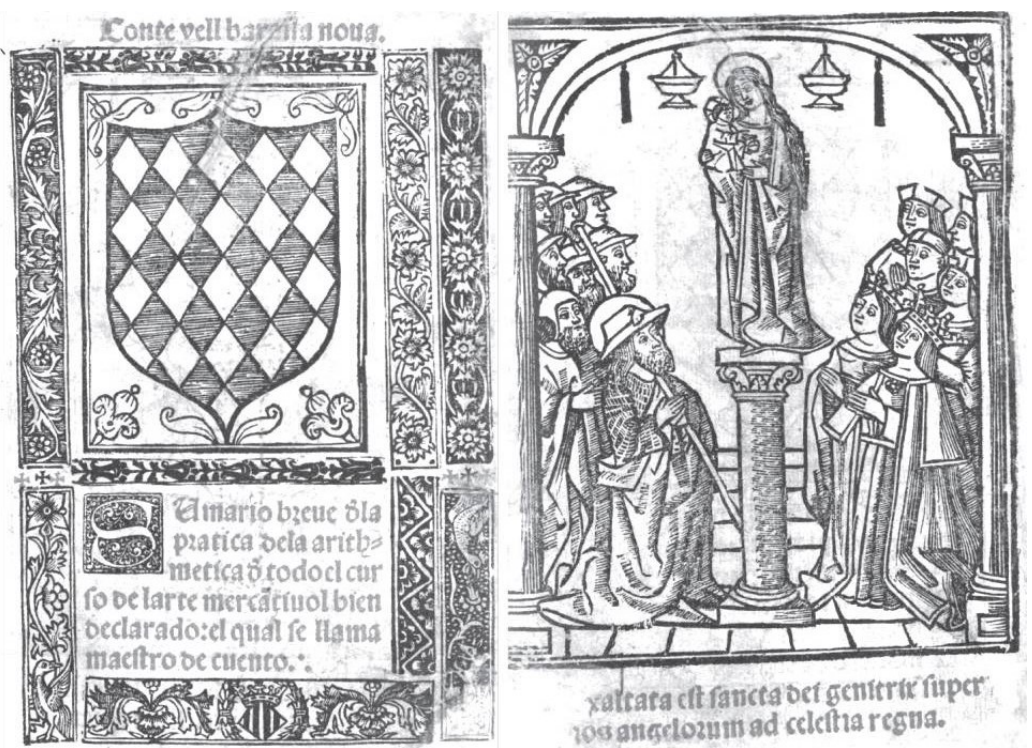

Figure 2. Cover of Juan Andres' book

In this book, Juan de Ortega aimed to help people avoid frauds related to accounts, because he considered that kind of arithmetic necessary for any person. In fact, according to his words, his book was useful to all men who want to learn this science, not as great arithmeticians but as simple accountants. In conclusion, Juan de Ortega believed that learning arithmetic and also geometry was necessary for any person and with this purpose did he publish his book. Therefore, it can be inferred that the book has a pedagogical and practical purpose.

\section{Juan Andres’ book}

Juan Andres was a priest (and an Islam jurist which converted to Catholicism according to Ausejo (2015)) known for being the author of one of the first books about arithmetic published in Spanish during this century: Sumario breve de la practica de la arithmetica de todo el curso del arte mercantivol bien declarado: el qual se llama maestro de cuento (Figure 2 shows the cover of the book), which was published in 1515 in Valencia (Picatoste, 1891).

With his book, Juan Andres aimed to help accountants so they could learn arithmetic, because he considered it very necessary for life. That is the reason why the book was written mainly for future 


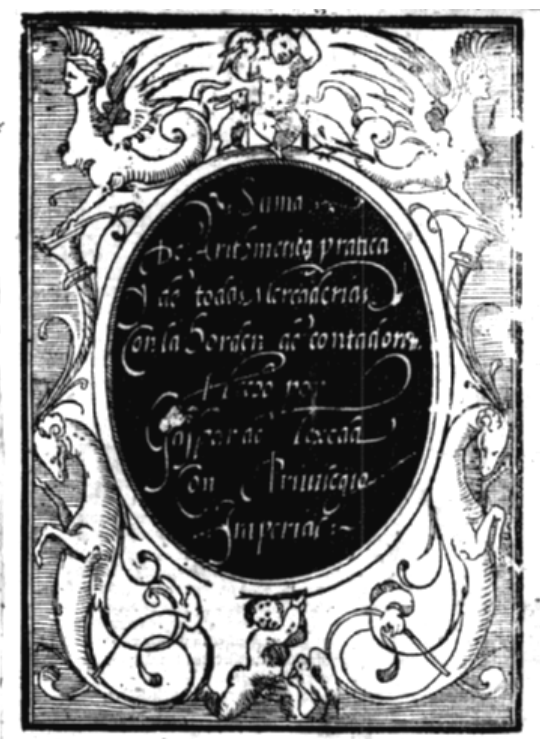

Figure 3. Cover of Gaspar de Texeda's book

accountants, so they could learn arithmetic and be good at their jobs with no need for a teacher. In addition, he valued the importance of the connections among mathematics and what he considered other sciences such as astrology, music, medicine, etc. On the whole and fundamentally, Juan Andres considered it important to have knowledge about arithmetic, so that this knowledge could be used in business deals; for example, he stated that knowledge about arithmetic will avoid deceptions and frauds in trade.

\section{Gaspar de Texeda's book}

More than three decades later, in 1546, the book Suma de Arithmetica practica y de todas mercaderias con la horden de contadores was printed in Valladolid (Figure 3 shows the cover of the book). Its author was Gaspar de Texeda, a priest according to (Salavert, 1990) although Ausejo (2015) discovered that he was a scrivener from Zaragoza, who wrote several other books that were not related to mathematics.

Gaspar de Texeda considered the main objective of his book that anyone without a teacher could become an accountant, and he consolidated this aim throughout his book. He wanted his readers to be able to use mathematics in real life situations because he believed that mathematics could be used in many different situations, like dealing with wills, inheritances or commercial relations. He even pointed out the importance of arithmetic in real life by choosing as an example precisely the difficulties in currency conversions and conversions among different units for measuring magnitudes.

This so, the aim of his work is that accountants could do their jobs right: calculate, keep their books and, above all, avoid being misled due to any lack of mathematical knowledge. Therefore, future accountants are the intended audience of his book.

\section{Juan de Yciar's book}

Juan de Yciar was a well-known calligrapher who published a large number of books. In addition to his work as a calligrapher, Juan de Yciar was also an occasional teacher (Ausejo, 2015; Picatoste, 1891).

The majority of the books written by Juan de Yciar focused on teaching how to write. Nevertheless, he published, in 1549 in Zaragoza, a book with mathematical contents: Libro intitulado Arithmetica practica muy util y provechoso para toda persona que quisiere exercitarse en aprender a contar (Figure 4 shows the cover of the book).

The intention of Juan de Yciar is made evident with the title of his book, which indicates that it will help anyone who wants to learn and practice how to count. In addition, in the prologue, Juan de Yciar stated the great importance that he gave to mathematics; he even added, in a letter to his readers, that arithmetic was of great use and great benefit. Therefore, this book was published with the aim to teach mathematics to any businessman and Juan de Yciar tried to include the most useful contents for them. 
Figure 4. Cover of Juan de Yciar's arithmetic book

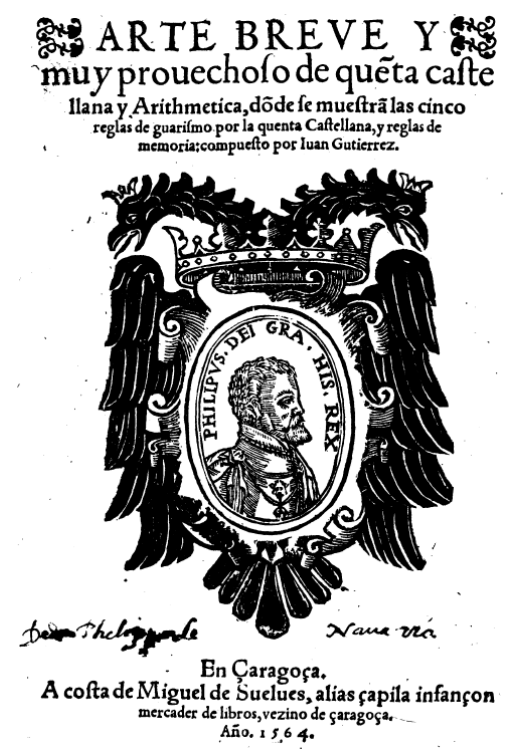

Figure 5. Cover of Gutierrez's book, that included a picture of Felipe II, the Spanish King during this period

This book is considered one of the arithmetic books that were likely being used during the second year of teaching Astrology at the University of Salamanca since 1561, in order to explain arithmetic from scratch and up to square and cube roots (Carabias, 2012). Ausejo (2015) considered that the fact that the book was printed in folio suggests that it was a book to be consulted and preserved, perhaps a book for the teacher, but maybe not a student manual.

\section{Juan Gutierrez's book}

The last book studied was written by Juan Gutierrez, a priest from a small Castilian town (Ausejo, 2015). Its title is Arte breve y muy provechoso de quenta castellana y Arithmetica, donde se muestra las cinco reglas de guarismo por la quenta castellana, y reglas de memoria, and it was printed in Zaragoza in 1564 (Figure 5 shows the cover of the book).

This book aimed to help men not to be deceived because of their lack of knowledge of basic mathematical operations. With this in mind, it is directed at the common folks, so that any man without a teacher could learn arithmetic and, more precisely, it is also designed to help future accountants to learn their job. 
Table 3. Target of the books

\begin{tabular}{lccc}
\hline & Anyone & Accountants & Businessman \\
\hline De Ortega (1512) & $\mathrm{X}$ & & \\
\hline Andres (1515) & & $\mathrm{X}$ & \\
\hline De Texeda (1546) & & $\mathrm{X}$ & $\mathrm{X}$ \\
\hline De Yciar (1549) & $\mathrm{X}$ & $\mathrm{X}$ & \\
\hline Gutierrez (1564) & $\mathrm{X}$ & & \\
\hline
\end{tabular}

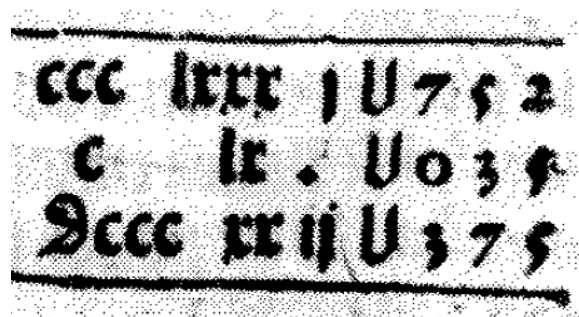

Figure 6. Combination of the positional numeration system with the Roman numeration (De Texeda, 1546, p. 5)

In comparing the aim of all these books, it becomes clear that all of them aim to teach arithmetic because it is consistently considered very relevant. This relevance derived from the fact that they wanted to help people avoid frauds related to count. To summarise, all the authors wrote their books with similar intentions.

Although the professions and the lives of the authors were not the same (as it is shown for example in Ausejo (2015)), the target of the books which they wrote is pretty similar, although small differences can be highlighted. Table 3 shows that some books were specifically written for accountants, that is professionals which work was counting, while others were written for anyone willing to learn how to count or specifically for businessman.

\section{Contents Included in the Books}

The analysed books present the following contents:

\section{Notion of number or quantity. Positional numeral system}

None of the books include a definition of number or quantity. All the authors begin their books with a (more or less) detailed explanation about the positional numeral system (several authors name this system as counting in alguarismo or guarismo). Also, some of them include the Roman numeration, authors like Gaspar de Texeda, Juan Gutierrez or Juan de Yciar name it as cuenta castellana (Castilian account), but Juan de Yciar states that Castilian account is in its first origin or speaking more properly Roman account because the Romans invented it.

A curious case stands out from Gaspar de Texeda's book; the author explains that foreigners in their books to write counts mix guarismos and Castilian account, they write guarismos until the thousands, they write then $U$ and from there, they use Castilian account (Figure 6).

It is relevant that these books were the main disseminators of the Arabic figures, which despite being known in Europe since the twelfth century were not commonly used until the development of mercantile activity of the sixteenth century. Therefore, this activity promoted the new numeral system and its calculus techniques (Paradís \& Malet, 1989).

Some authors include contents about theoretical arithmetic. For example, different topics about numbers like their properties or their different kinds.

\section{Elementary operations}

After explaining the numeral positional system, these books present several chapters about the four operations: addition, subtraction, multiplication and division. The difficulty of the multiplication algorithm, maybe related to the difficulty of memorizing the times tables, is reflected in the inclusion of numerous examples of multiplication, rules to remember the tables and even different multiplication algorithms, which are not proved. 
However, none of these chapters about operations mention the properties of these, although some of them are taken for granted. For example, the multiplication tables presented by Gaspar de Texeda assumed the commutative property of this operation by not reflecting both multiplicative pairs (that is including $2 \times 3=6$ but not $3 \times 2=6)$.

All the authors include different proofs to check if the result of an operation is right.

\section{Definition of fractions and operations with them}

With the exception of Gutierrez's, all the other books included fractions or operations with them (change fractions into fractions with common denominators; addition, subtraction, multiplication and division of fractions). Among the authors who include a definition of this concept, it is mostly widespread to consider that a fraction, frequently referred to as a broken number, is a part of the whole number or a thing that is not whole.

\section{Notion of proportion or exercises related to it, like rule of three, etc.}

None of the books includes any definition of proportion. However, all of them include, to a greater or lesser extent, exercises about the rule of three or rule of company. Despite the fact that these rules carry implicit the notion of proportion, it is not explained by the authors.

The problems included are exercises on the rule of three, both directly and inversely proportional, simple and compound; on proportional distributions; on percentages, and on false position methods.

The contexts in which these problems are set are mainly related to business. For example, the use of the rule of three and percentages is worked on through problems in which a certain amount of money is invested for a particular period of time and produces some benefit or a certain loss. The problems ask typically to find out how much the gain or loss will amount to if the initial investment either increases or decreases. Others focus on how to find out what the price of an object should be set to in order to gain a particular percentage of benefit, or to lose only a small percentage.

Proportional distributions are used to know the equitable distribution of objects or profits, or to distribute the profitability in a deposit, a business, a will, to a mixture of products, etc.

Other problems refer to situations that have the rule of three or the false position methods applied to salaries, rents and other payments as an excuse for their use. For example, the salary that has to be paid to one or more workers if they work for a certain time and several initial conditions apply.

There were also problems of alloys and ligatures among metals, dealing with several specifications previously given. For example, the values that would be obtained if two pieces of gold of different carat were joined or how different currencies were formed with alloys of different metals.

\section{Progression}

All the books include progressions, although not all of them include its definition. Among the definitions, Juan Andres (1515) says that a progression is when many numbers are placed on top of each other in such a way that the following exceeds the previous one in certain units and he adds that exceeding must be equal in all numbers of such progression.

The books include types of progression with examples of calculations of the sum of terms. Some books include the chessboard tale related to counting the number of grains of wheat per square as an example of progression.

Also, Gaspar de Texeda or Juan de Yciar propose contextualized examples for progressions, like this one proposed by Gaspar de Texeda (1546): Two people take on a journey, the first walks 20 leagues (former unit of length) every day, the $2^{\text {nd }}$ one walks one league the first day, two leagues the $2^{\text {nd }}$ day, three leagues the $3 r d$ day and so on, one more league each day. And the problem asks: how many days will the $2^{\text {nd }}$ walker need to reach the first walker? This author contextualizes progressions not only in walkers and journeys, but also in money or in quantities of wheat.

\section{Extraction of square or cube roots}

Some authors include the extraction of square and cube roots from natural numbers or from fractions. Authors, like Juan de Yciar (1549), state that when a suggested number is multiplied by itself, it results in what we call square and the initial number is called the root of that square number. 


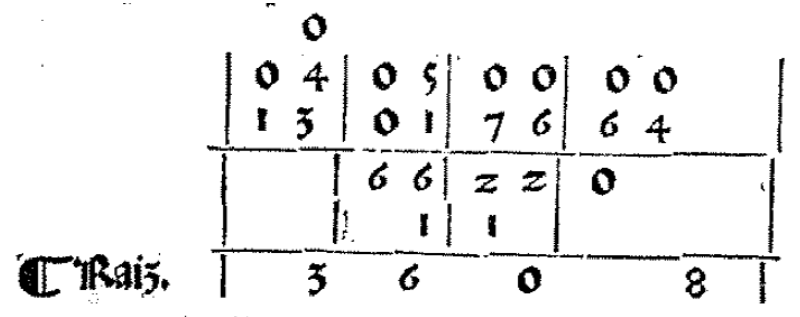

Figure 7. Square root (De Ortega, 1512, p. 28)

And the authors show different examples on how to extract a root, for example the extraction of the square root of the number 13017664 proposed by Juan de Ortega (Figure 7).

\section{Ideas about geometry}

Despite being books focused on arithmetic, some authors include ideas about geometry, for example Juan de Ortega includes a last section about this topic with different practical examples. Or Gaspar de Texeda who also includes a section about geometry in which, in addition to different practical examples, he includes a paragraph about geometry words.

The concepts related to geometry included in these books appear mostly linked either to the square roots, or to problems about measurement of land. In many occasions, the realisation of some exercises implies knowledge about theorems such as Thales or about different geometric properties, even though these are not formally explained. Moreover, when authors like Juan de Ortega or Juan de Yciar make exercises about circumferences and circles, they use the approximation from number $\mathrm{Pi}$ : $3+1 / 7$.

The books include problems that point at finding the length of objects, distances or routes, also those related to time measurement. For example, to know the measure of an object or the distance between two buildings given certain initial conditions, or to calculate the dimensions of a piece of land considering several properties related to its geometric shape.

In addition, Juan Andres makes different classifications for numbers and one of them is according to geometry; he differentiates among linear, surface, square, solid numbers, etc. Therefore, in these books different examples of geometric content and different connections between geometry and arithmetic can be found.

\section{Currencies and measures}

A last common feature included in all the books is a variety of currencies and measures. This reflects the needs of this knowledge in that period and the difficulties that the equivalences among them caused to businessmen at the time.

It can be stated that these books show the great complexity of currency equivalence and measuring at the time, because, despite the proximity in date of publication among them, they did not present the same equivalences, for example, among currencies, nor even in each book do they abstain from giving more than one possible value for common currencies, or different values for units of measure depending on the product to be measured.

In a period like the beginning of the sixteenth century, in which different regions had different currencies and measures, it is reasonable to think that they gave great importance to learn how to calculate in order to avoid deceit in commercial deals.

To summarise, it is observed that all the authors include similar contents related to arithmetic and more focused on the practical applications of it than in formal theory. All authors include basic operations, exercises related to proportion, progressions and currencies and measures. The only differences among the contents of the books are that Juan Gutierrez does not include any definition of fractions or operations with them nor includes he the extraction of roots, and that Juan Andres does not barely include any geometric ideas. The books focus mostly on explaining basic arithmetic contents. There are no major differences among the books and other books published at the time or even before; in fact, some authors recognise that other authors' books like Lucas de Burgo's treatise influenced their writings greatly. 
As an exception, Gaspar de Texeda made an original contribution in his book with the inclusion of a few pages dedicated to the Rules for Accountants, which has led to the book's consideration as the first Spanish book that deals with bookkeeping from a purely technical point of view (González, 1956).

These books responded to a social need that came up during this century due to the increase of the trade relations and, for this reason, they all include almost the same contents and exercises. May the following problem illustrate this:

- If a diamond, a pearl or any other piece of jewellery that weighs two grams and it costs 20 ducats (type of coin used during this period in some regions in Spain and other places of Europe), how much more will another piece of jewellery, that weighs four grams, cost as compared with the first one?

This exact problem is included in Juan de Ortega's book, Juan de Yciar's book and Juan Gutierrez's book, although the first one included different weights and prices of the pearls.

Another example is the following one:

- $\quad$ Three men made a company; the first contributed with 34 ducats to the company, the second with 28 ducats and the third with 48 . When they finished the company, they had earned 48 ducats. How much money should each of them receive?

This problem, with different quantities is included in Juan Andres' book, Juan de Yciar's book, Juan de Ortega's book and Gaspar de Texeda's book.

On the whole, these books highlight authors' concern for the difficulties faced by traders because of mathematics and how all authors try to teach them how to solve such problems by including a small number of contents but a large variety of similar applied examples.

\section{CONCLUSIONS}

The growing need for practical arithmetic that emerged during the sixteenth century led to the publication of several books whose aim was to teach these contents. This comparative analysis confirms the hypotheses presented previously by different authors and allows characterizing these mathematics books as manuals whose contents aimed to satisfy the demand of the time for basic mathematical knowledge focused in its commercial applications. That is the reason why they all include mostly basic mathematical contents and, above all, a plethora of examples and exercises to help readers understand these contents. The target of these books is also pretty similar and the fact that several authors wrote their books for anyone willing to learn shows their pedagogical interest.

As the contents and examples presented previously show, all of them are pretty similar books whose main feature is their social interest. As stated before, arithmetic was seen as a useful tool with different applications and even as an aid for social improvement. For this reason, most of the numerous examples found in the books are contextualised into situations related in one way or another to commercial deals.

In conclusion, the analysed books, despite not presenting mathematical advances, have a relevant instrumental value. The authors were concerned with the problems and needs of their time and they tried to aid common financial and commercial operations, which is why they include different exercises and examples that aim to serve as a model for other possible situations that may occur in trade activities of that time. Therefore, this study has shown that the authors of the sixteenth century took into account the daily needs of their contemporary society and wanted to bring mathematics closer to those needs.

\section{Disclosure statement}

No potential conflict of interest was reported by the authors.

\section{Notes on contributors}

María José Madrid - Universidad Pontificia de Salamanca, Spain.

Alexander Maz-Machado - Universidad de Córdoba, Spain.

Carmen López - Universidad de Salamanca, Spain.

Carmen León-Mantero - Universidad de Córdoba, Spain. 


\section{REFERENCES}

Andres, J. (1515). Sumario breve de la practica de la arithmetica [Brief summary of practical arithmetic]. Valencia: Juan Joffre.

Ausejo, E. (2015). New Perspectives on Commercial Arithmetic in Renaissance Spain. In D. E. Rowe \& W. Horng (Eds.), A Delicate Balance: Global Perspectives on Innovation and Tradition in the History of Mathematics (pp. 181-207). Basel: Springer. https://doi.org/10.1007/978-3-319-12030-0_9

Blanco, M. (2013). The Mathematical Courses of Pedro Padilla and Étienne Bézout: Teaching Calculus in Eighteenth-Century Spain and France. Science \& Education, 22(4), 769-788. https://doi.org/10.1007/s11191-012-9537-6

Burke, P. (2000). A Social History of Knowledge: From Gutenberg to Diderot. Cambridge: Polity Press. https://doi.org/10.1353/jsh.2000.0001

Carabias, A. M. (2012). Salamanca y la medida del tiempo [Salamanca and the time measurement]. Salamanca: Ediciones Universidad de Salamanca.

Carpenter, D. I. (2013). Adam Riese. In F. J. Swetz (Ed.), The European Mathematical Awakening: A Journey Through the History of Mathematics from 1000 to 1800 (pp. 45-49). New York: Dover Publications.

Caunedo, B. (2009). Un manual de aritmética mercantil de Mosén Juan de Andrés [A manual of mercantil arithmetic by Mosén Juan de Andrés]. Pecunia: Revista de la Facultad de Ciencias Económicas y Empresariales, Universidad de León, 8, 71-96. https://doi.org/10.18002/pec.v0i8.675

Choppin, A. (2000). Los manuales escolares de ayer a hoy: el ejemplo de Francia [School handbooks from yesterday to today: the french example]. Historia De La Educación, 19, 13-37.

Clark, K., \& Robson, E. (2008). Ancient accounting in the modern mathematics classroom. BSHM Bulletin, 23(3), 129-142. https://doi.org/10.1080/17498430802304008

Cockcroft, W. H. (1982). Mathematics counts. London: HM Stationery Office.

De Ortega, J. (1512). Conpusicion de la arte de la arismetica y Juntamente de geometria [Composition of the art of arithmetic and together with geometry]. Lyon: casa de Maistro Nicolau de Benedictis.

De Texeda, G. (1546). Suma de Arihtmetica Practica y de todas Mercaderias con la horden de contadores [Sum of practical arithmetic and all merchandise with the order of accountants]. Valladolid: Oficina de Francisco Fernández de Córdoba.

De Yciar, J. (1549). Arithmetica Practica [Practical arithmetic]. Zaragoza: Casa de Pedro Bernuz.

Fauvel, J. (1991). Using history in mathematics education. For the Learning of Mathematics, 11(2), 3-6.

Fauvel, J., \& van Maanen, J. A. (Eds.). (2000). History in mathematics education: The ICMI study. Dordrecht: Kluwer Academic Publishers.

Frejd, P. (2012). Old algebra textbooks: a resource for modern teaching. BSHM Bulletin: Journal of the British Society for the History of Mathematics, 28(1), 25-36. https://doi.org/10.1080/17498430.2012.676963

Garciadiego, A. R. (2002). History of Mathematics, an Intuitive Approach. Humanistic Mathematics Network Journal, 26, 6-11. https://oi.org/10.5642/hmnj.200201.26.05

Gómez, B. (2001). La justificación de la regla de los signos en los libros de texto: ¿Por qué menos por menos es más? [Justification of the rule of signs in textbooks: why negative times negative is positive?]. In $\mathrm{P}$. Gómez \& L. Rico (Eds.), Iniciación a la investigación en didáctica de la matemática. Homenaje al profesor Mauricio Castro (pp. 257-275). Granada: Universidad de Granada.

González, J. M. (1956). Gaspar de Texeda, precursor de la teneduría de libros en España [Gaspar de Texeda, precursor of the bookkeeping in Spain]. Técnica Económica: Administración y dirección de empresas, 2, 36-43.

Grattan-Guinness, I. (2004). The mathematics of the past: distinguishing its history from our heritage. Historia Mathematica, 31, 163-185. https://doi.org/10.1016/S0315-0860(03)00032-6

Gulikers, I., \& Blom, K. (2001). 'A historical angle', a survey of recent literature on the use and value of history in geometrical education. Educational Studies in Mathematics, 47(2), 223-258. https://doi.org/10.1023/A:1014539212782

Gutiérrez, J. (1564). Arte Breve y muy provechoso de quenta castellana y Arithmetica [Brief and very useful art of Castilian count and arithmetic]. Zaragoza: casa de Pedro Bernuz.

Hallez, M. (1992). Teaching Huygens in the rue Huygens: Introducing the history of 17th-century mathematics in a junior secondary school. Science \& Education, 1(3), 313-328. https://doi.org/10.1007/BF00430279 
Jahnke, H. N. (2001). Cantor's Cardinal and Ordinal Infinities: an Epistemological and Didactic View. Educational Studies in Mathematics, 48(2), 175-197. https://doi.org/10.1023/A:1016052726876

Jankvist, U. T. (2009). A categorization of the "whys" and "hows" of using history in mathematics education. Educational studies in Mathematics, 71(3), 235-261. https://doi.org/10.1007/s10649-008-9174-9

Kiliari, E. Gagatsis, A., \& Papadaki, I. (2015). The first Greek printed mathematics book: The famous book of arithmetic Accounting of Manolis Glyzounis. International Journal for the History of Mathematics Education, 10(1), 25-53.

Kilpatrick, J. (1994). Historia de la investigación en educación matemática [History of research in mathematics education]. In J. Kilpatrick, L. Rico \& M. Sierra (eds), Educación matemática e investigación (pp. 13-96). Madrid: Síntesis.

Kjeldsen, T. H. (2011). Uses of history in mathematics education: development of learning strategies and historical awareness. In M. Pytlak, T. Rowland and E. Swoboda (eds), Proceedings of the Seventh Congress of the European Society for Research in Mathematics Education (CERME 7, February 9- 13, 2011) (pp. 1700-1709). Rzeszów, Poland: University of Rzeszów and ERME.

López, J. M. (1979). Ciencia y técnica en la sociedad española de los siglos XVI y XVII [Science and technique in the Spanish society of the 16th and 17th centuries]. Barcelona: Labor.

Madrid, M. J. (2016). Los libros de aritmética en España a lo largo del siglo XVI [Arithmetic books in Spain during the 16th century]. Doctoral dissertation, Salamanca: Universidad de Salamanca.

Madrid, M. J., Maz-Machado, A., León-Mantero, C., \& López-Esteban, C. (2017). Aplicaciones de las matemáticas a la vida diaria en los libros de aritmética españoles del siglo XVI [Applications of mathematics to everyday life in Spanish arithmetic books published in the 16th century]. Bolema: Boletim de Educação Matemática, 31(59), 1082-1100. https://doi.org/10.1590/1980-4415v31n59a12

Marco-Buzunáriz, M. A., Muñoz-Escolano, J. M., \& Oller-Marcén, A. M. (2016). Investigación sobre libros de texto en los simposios de la SEIEM (1997-2015) [Research on textbooks on the Symposia of the SEIEM (1997-2015)]. In A. Berciano, C. Fernández, T. Fernández, J. L. González, P. Hernández, A. Jiménez, J. A. Macías, F. J. Ruiz, M. T. Sánchez (Eds.), Investigación en Educación Matemática XX (pp. 325-334). Malaga, Spain: Universidad de Málaga.

Maz, A. (2005). Los números negativos en España en los siglos XVIII y XIX [Negative numbers in Spain in the 18th and 19th centuries]. Doctoral dissertation, Granada: Universidad de Granada.

Maz, A. (2009), Investigación histórica de conceptos en los libros de matemáticas [Historical research of concepts in mathematics books]. In M.J. González, M.T. González \& J. Murillo (Eds.), Investigación en Educación Matemática XIII (pp. 5-20). Santander: SEIEM.

Maz, A., \& Rico, L. (2009). Negative numbers in the 18th and 19th centuries: phenomenology and representations. Electronic Journal of Research in Educational Psychology, 17(1), 537-554.

Maz-Machado, A., Madrid, M. J., León-Mantero, C., \& Jiménez-Fanjul, N. (2017). Research trends in the history of mathematics education: the Spanish case. In K. Patterson (Ed.), Focus on mathematics education research (pp. 150-182). New York: Nova.

Meavilla, V., \& Oller, A.M. (2014). El simbolismo algebraico en tres álgebras españolas del siglo XVI [Algebraic symbolism in three Spanish books on Algebra from the 16th century]. Números, 87, 59-68.

Meavilla, V., \& Oller, A.M. (2014). La extracción de raíces en el Tratado de Mathematicas (1573) del bachiller Juan Pérez de Moya [The extraction of roots in the Tratado de Mathematicas (1573) of the bachelor Juan Pérez de Moya]. Epsilon, 88(33-1), 71-88.

O’Connor, J. J., \& Robertson, E. F. (2019). MacTutor History of Mathematics archive. Scotland: University of St Andrews. Retrieved on 6 March 2019 from http://www-history.mcs.st-andrews.ac.uk/index.html

Paradís, J., \& Malet, A. (1989), La génesis del álgebra simbólica. (Vol. I). Los orígenes del álgebra: de los árabes al renacimiento [The genesis of symbolic algebra (Vol. I). The origins of algebra: from the Arabs to the Renaissance]. Barcelona: PPU.

Picado, M. E. (2012). El sistema métrico decimal en libros de texto de matemáticas en España durante la segunda mitad del siglo XIX (1849-1892) [The metric system in mathematics textbooks in Spain during the second half of the 19th century (1849-1892)]. Doctoral dissertation, Granada: Universidad de Granada. 
Picado, M., \& Rico, L. (2012). La introducción del sistema métrico decimal y los libros de texto en España [The Introduction of Metric System and the Textbooks in Spain]. Suma: Revista Sobre Enseñanza $y$ Aprendizaje De Las Matemáticas, 71, 9-18.

Picatoste, F. (1891). Apuntes para una biblioteca científica española del siglo XVI: estudios biográficos y bibliográficos de ciencias exactas, físicas y naturales y sus inmediatas aplicaciones en dicho siglo [Notes for a Spanish scientific library of the 16th century: biographical and bibliographic studies of exact, physical and natural sciences and their immediate applications in this century]. Madrid: Manuel Tello.

Puig, L., \& Fernández, A. (2013). La Arithmetica Algebratica de Marco Aurel, primer álgebra impresa escrita en español. Preliminares para su estudio [Arithmetica Algebratica by Marco Aurel, the first printed algebra written in Spanish. Preliminaries for its study]. In L. Rico, M. C. Cañadas, J. Gutiérrez, M. Molina, I. Segovia (eds.), Investigación en Didáctica de la Matemática. Homenaje a Encarnación Castro (pp. 143-150). Granada, España: Editorial Comares.

Rey, J. (1934). Los matemáticos españoles del siglo XVI [Spanish mathematicians of the 16th century]. Madrid: Junta de Investigaciones Histórico-Bibliográficas.

Salavert, V. (1990). Introducción a la historia de la aritmética práctica en la Corona de Aragón en el siglo XVI [Introduction to the history of practical arithmetic in the kingdom of Aragon in the 16th century]. Dynamis: Acta Hispanica Ad Medicinae Scientiarumque. Historiam Illustrandam, 10, 63-91.

Salavert, V. L. (1994), Aritmética y sociedad en la España del siglo XVI [Arithmetic and society in Spain in the 16th century. In S. Garma, V. Navarro, D. Flament (Eds.), Contra los gigantes de la rutina. Investigaciones sobre Historia y Filosofía de las Matemáticas. (pp. 51-69). Madrid: CSIC.

Schubring, G. (1987). On the methodology of analysing historical textbooks: Lacroix as textbook author. For the Learning of Mathematics, 7(3), 41-50.

Schubring, G. (2006). Researching into the History of Teaching and Learning Mathematics: the State of the Art. Paedagogica Historica, 42(4-5), 665-677. https://doi.org/10.1080/00309230600806955

Schubring, G. (2014). On Historiography of Teaching and Learning Mathematics. In A. Karp \& G. Schubring (Eds.), Handbook on the history of mathematics education (pp. 3-8). New York: Springer. https://doi.org/10.1007/978-1-4614-9155-2_1

Sierra, M., Rico, L., \& Gómez, B. (1997). El número y la forma: libros e impresos para la enseñanza del cálculo y la geometría [The number and the form: books and printed texts for teaching calculation and geometry]. In A. Escolano (Ed.), Historia ilustrada del libro escolar en España: del Antiguo Régimen a la Segunda República (pp. 373-398). Fundación Germán Sánchez Ruipérez: Ediciones Pirámide.

Swetz, F. (1992). Fifteenth and sixteenth century arithmetic texts: What can we learn from them? Science \& Education, 1, 365-378. https://doi.org/10.1007/BF00430963 